\title{
Transpiration Capacity in Poinsettia Cuttings at Different Rooting Stages and the Development of a Cutting Coefficient for Scheduling Mist
}

\author{
Erin G. Wilkerson and Richard S. Gates \\ Department of Biosystems and Agricultural Engineering, University of Kentucky, Lexington, \\ KY 40546 \\ Sérgio Zolnier \\ Agricultural Engineering Department, Federal University of Viçosa, Brazil
}

Sharon T. Kester and Robert L. Geneve

Department of Horticulture, University of Kentucky, Lexington, KY 40546

\begin{abstract}
AdDitional INDEX woRDs. Euphorbia pulcherrima, vapor pressure deficit, adventitious root formation, relative water content, cutting coefficient

Abstract. Rooting stage, transpiration capacity, and relative water content were measured in cuttings every 5 days for 25 days. Cell divisions in phloem parenchyma were evident between 5 and 10 days after sticking, organized subcuticular root primordia were present between 10 and 12 days, and roots emerged between 12 and 15 days. Transpiration was measured in poinsettia (Euphorbia pulcherrima Willd. ex Klotzsch 'Freedom Dark Red') cuttings under light or dark conditions at increasing vapor pressure deficit (VPDair) levels during different stages of rooting. Transpiration capacity did not increase until roots emerged on the cuttings. Light had a significant impact on transpiration rates only after roots emerged. Light was more significant than VPDair for determining actual transpiration. Between visible rooting (15 days) and 25 days, increase in total root length was linear $\left(r^{2}=0.92\right)$ and significantly correlated with transpiration $\left(r^{2}=0.98\right)$. Transpiration capacity increased after visible rooting, but did not significantly increase under non-misted conditions until cuttings were well-rooted and had a total root length $>50 \mathrm{~cm}$ (18 days after sticking). Relative water content measured before and after entering the transpiration chamber confirmed that cuttings were only able to take enough water from the medium to continue sustained transpiration after 18 days. A cutting coefficient was developed from transpiration data to modify the misting interval for dynamic controlled misting. Greenhouse studies showed a $\mathbf{5 5 \%}$ or greater reduction in water use with dynamic control compared to constant static or stepped down static control. Rooting performance was unaffected by misting interval. Foliar nutrition was significantly reduced in all cuttings after 7 days in the mist bench, but changes in foliar elemental content were not correlated with misting interval.
\end{abstract}

A dynamic mist control system for rooting poinsettia cuttings was developed based on estimated cutting evapotranspiration (Zolnier et al., 2003). The evapotranspiration-based system offers several advantages over traditional statically controlled mist systems (i.e., mist applied for a given amount of time at set intervals). Static mist controllers are inexpensive and easily installed, but they are unable to respond to daily fluctuations in light irradiance, cloud-cover, relative humidity, and temperature or stage of root development (Hartmann et al., 2002). In moderate conditions, static misting control systems are capable of reducing the evaporative demand by reducing the air vapor pressure deficit quite effectively. However, cuttings will receive too frequent misting on cloudy days when solar radiation is low and less than adequate mist on very sunny days when the net radiation is high (Zolnier, 1999). Insufficient misting that inadequately controls VPDair can result in poor cutting water status reducing rooting potential and leading to possible crop damage. There are also negative effects associated with over applying mist such as leaching of foliar nutrients and saturation of the propagation medium limiting available oxygen (Gislerød, 1983).

Received for publication 14 Jan. 2004. Accepted for publication 22 Sept. 2004. Univ. of Kentucky Experiment Station publication \#03-11-142. This work was partially funded through a grant from the Gloeckner Foundation.
Parameters for the evapotranspiration-based mist control system (Zolnier et al., 2003) were developed by measuring evapotranspiration of fully rooted cuttings with partially wetted leaves from mist at various light (0 to $\left.300 \mathrm{~W} / \mathrm{m}^{2}\right)$ and VPDair levels $(0.5$ to $2.5 \mathrm{kPa})$. It was hypothesized that higher frequency misting intervals would be required during conditions of high transpirational demand and for unrooted cuttings. Intuitively, mist frequency should be progressively decreased as cuttings root and are able to take water from the medium to contribute to the cutting's water status.

In growth chamber studies, the evapotranspiration-based model overestimated actual evapotranspiration for partially and fully rooted cuttings during lighted periods by as much as $14 \%$ (Zolnier et al., 2003). It was suggested that the ability of the model to predict evapotranspiration was reduced as the misting frequency was diminished due to high transpiration demand under high light conditions. The actual contribution of water uptake from the substrate, related to the cutting's stage of rooting development, could also account for the variation in predicted versus actual evapotranspiration. Therefore, the objective of the present study was to measure transpiration in poinsettia cuttings at well-established stages of rooting and to characterize the water relations in these cuttings. In addition, total root length following root initiation was correlated with cutting transpiration to measure the capability of the cutting to take up water. 


\section{Materials and Methods}

Stock PLANTS AND RoOting CONDITIONS. Six- to eight-cm poinsettia cuttings were taken from greenhouse-grown stock plants maintained in 11-Lcontainers between May and September. Cuttings were rooted either in greenhouse mist beds or in three controlled environmental chambers.

Cuttings were stuck in either Oasis rootcubes (No. 5015; Oasis Grower Products, Kent, Ohio) or $5 \times 5 \times 6-\mathrm{cm}$ Anderson band containers (Anderson Manufacturing, Portland, Ore.) filled with a Metromix 350 (Scotts-Sierra Horticultural Products, Marysville, Ohio) and perlite (8:3, v/v; $15.5 \mathrm{~g}$ dry weight) medium. Cuttings in Oasis were used in initial experiments to measure transpiration for the entire population of cuttings within environmental chambers. Cuttings in Metromix plus perlite rooting medium were used in all subsequent experiment because it allowed easy removal of the cuttings for evaluation of rooting stage and root length.

Three greenhouse mist beds $(1 \times 1 \times 1.2 \mathrm{~m})$ were constructed using clear polycarbonate sheets supported on an aluminum frame (Geneve et al., 2004). One side of the chamber was open to the greenhouse. There was a single mist line per chamber with four Netafim Dan fogger nozzles (Netafim, Fresno, Calif.) placed 1 $\mathrm{m}$ above the chamber base. Each line was connected to separate Richdel 24-V globe solenoids and mist intervals set using a Gemini 6 controller with Sun-Sensor (Phytotronics, Earth City, Mo.) or controlled by a personal computer running the evapotranspiration misting model (dynamic control) developed by Zolnier et al. (2003). Each mist burst lasted $5 \mathrm{~s}$ and delivered water at 1200 $\mathrm{mL} \cdot \mathrm{m}^{-2} \cdot \mathrm{h}^{-1}$. The computer recorded air temperature, time interval between misting events, and calculated air vapor pressure deficit every minute. The greenhouse mist chambers received $60 \%$ shade. Each bed contained 72 cuttings.

Environmental chambers were constructed to control substrate temperature, air temperature, vapor pressure deficit, and light. These have been previously described in detail (Wilkerson and Gates, 2003; Zolnier et al., 2001). Briefly, cuttings were placed in separate $68 \times 5 \times 5$-cm aluminum trays (14 cuttings per tray) on an aluminum thermogradient plate within each chamber set to maintain a constant $25^{\circ} \mathrm{C}$ medium temperature. The air temperature within the chambers was $24{ }^{\circ} \mathrm{C}$ with a VPDair of $0.78 \mathrm{kPa}$. Light (40-W cool-white fluorescent tubes plus 100-W incandescent bulbs) was provided for a 12 -h photoperiod with photosynthetic active radiation $(P A R)$ of $118 \mu \mathrm{mol} \cdot \mathrm{m}^{-2} \cdot \mathrm{s}^{-1}$. Just after cuttings were stuck the mist interval was set at $15 \mathrm{~min}$. This interval was gradually increased during rooting based on visual observations of cutting water stress. The mist interval when cuttings were fully rooted was $30 \mathrm{~min}$.

STAGES OF ROOT FORMATION. In initial experiments using Oasis cubes, the stage of rooting was estimated by visual observation of greenhouse propagated cuttings. Six stages were established as: at excision; one week following excision (7 d); visible rooting (14 d); one week after visible rooting (21 d); two weeks following visible rooting ( $28 \mathrm{~d})$; and fully rooted (35 d).

In follow-up experiments, the precise stage of rooting was measured for each cutting used to measure transpiration. Prior to visible rooting, the basal (proximal) $1 \mathrm{~cm}$ of each cutting was cut into $25-\mu \mathrm{m}$ sections using a Vibratome tissue-sectioning system (Vibratome, St. Louis). Rooting stages were placed into one of five discrete numerical development stages: $0=$ no rooting activity; $1=$ undifferentiated cell division prior to organized root formation; 2 = organized subcutaneous root initials; 3 = visible root emergence beyond the epidermis; and $4=$ emerged roots
$>5 \mathrm{~mm}$ (Fig. 1). Nine cuttings were sampled every $3 \mathrm{~d}$ for $24 \mathrm{~d}$. Post-emergent root length was measured using MacRhizo (Régent Instruments, Quebec, Canada) software of digital images taken using a flat bed scanner (Geneve and Kester, 2001).

Cutting water Relations. Steady-state transpiration was initially measured in cuttings rooted in the greenhouse and moved to two replicate environmental chambers at estimated stages of rooting. Cuttings were exposed to several levels of light (incident radiation at 0,50 , or $200 \mathrm{~W} / \mathrm{m}^{2}$ ) in combination with three VPDair levels $(1.0,1.5,2.0 \mathrm{kPa})$. Each chamber contained 49 cuttings placed on a digital balance (model B50S05; Ohaus Corp., Florham Park, N.J.). Water content was 50 g per root cube. The medium was covered with plastic to prevent evaporation. Weight change was measured every $5 \mathrm{~min}$ for $6 \mathrm{~h}$ for stages prior to root emergence and $3 \mathrm{~h}$ for post rooting stages.

Subsequently, transpiration was measured in cuttings rooted in three replicate environmental chambers at precise stages of rooting. To determine transpiration rate, a tray of 12 cuttings was removed from the propagation chamber and weighed on a 4800-g capacity electronic balance (model VIR-4800; Acculab, Newtown, Pa.) housed in a separate chamber with a $240-\mathrm{W} / \mathrm{m}^{2}$ radiant load (radiant source: $100-\mathrm{W}$ incandescent bulbs) and $0.8 \mathrm{kPa}$ VPDair. Each tray had a Plexiglas cover into which each cutting was placed and the ends of each tray were covered with parafilm to prevent water loss by evaporation. Background water loss from trays without cuttings was subtracted from trays containing cuttings.

Steady-state transpiration rate was taken as the slope of a least squares regression analysis of the time-series recording of weight after excess mist water was dried from the leaves and tray (90 to 120 min after cutting trays were removed from the mist environment). On each sample day, three trays were measured per treatment.

Relative water content [(fresh weight minus dry weight) divided by (turgid weight minus dry weight) multiplied by 100] was determined using three $1-\mathrm{cm}^{2}$ leaf disks (no midvein tissue) per cutting (Turner, 1981). Three disks were punched from a single leaf and pooled in a single sample. The fresh weight of a sample was the weight of the three leaf discs immediately after being punched from the leaf. The discs were then floated in a petri dish of deionized distilled water and kept dark at $1{ }^{\circ} \mathrm{C}$ for $24 \mathrm{~h}$. At this time the samples were blotted dry and the turgid weight determined. Dry weight was measured after oven drying at $100{ }^{\circ} \mathrm{C}$ for $24 \mathrm{~h}$. Relative water content was calculated prior (prestress) and after (post-stress) entering transpiration chambers. Three cuttings per replicate were used to establish prestress and nine cuttings per replicate were used for post-stress determination. There were three replicates per treatment.

Cutting Coefficient. A cutting coefficient was calculated as the dimensionless ratio between water uptake at a given rooting stage and transpiration demand of the physical environment. Transpiration demand was estimated for fully rooted cuttings using the Penman-Monteith model from previous work (Zolnier et al., 2001). Transpiration rates were measured under various light and VPDair conditions as indicated earlier and plotted against estimated transpiration demand. Cutting coefficients were determined as the slope of the linear regression.

Cutting performance and water use efficiency were compared between cuttings rooted in the greenhouse with misting controlled by a static controller or dynamic evapotranspiration control. Two replicate chambers contained 72 cuttings for each misting system. The static control was stepped-down every $7 \mathrm{~d}$ from 144 to 72 to 


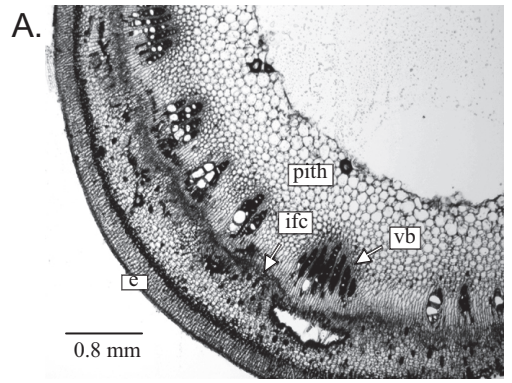

B.
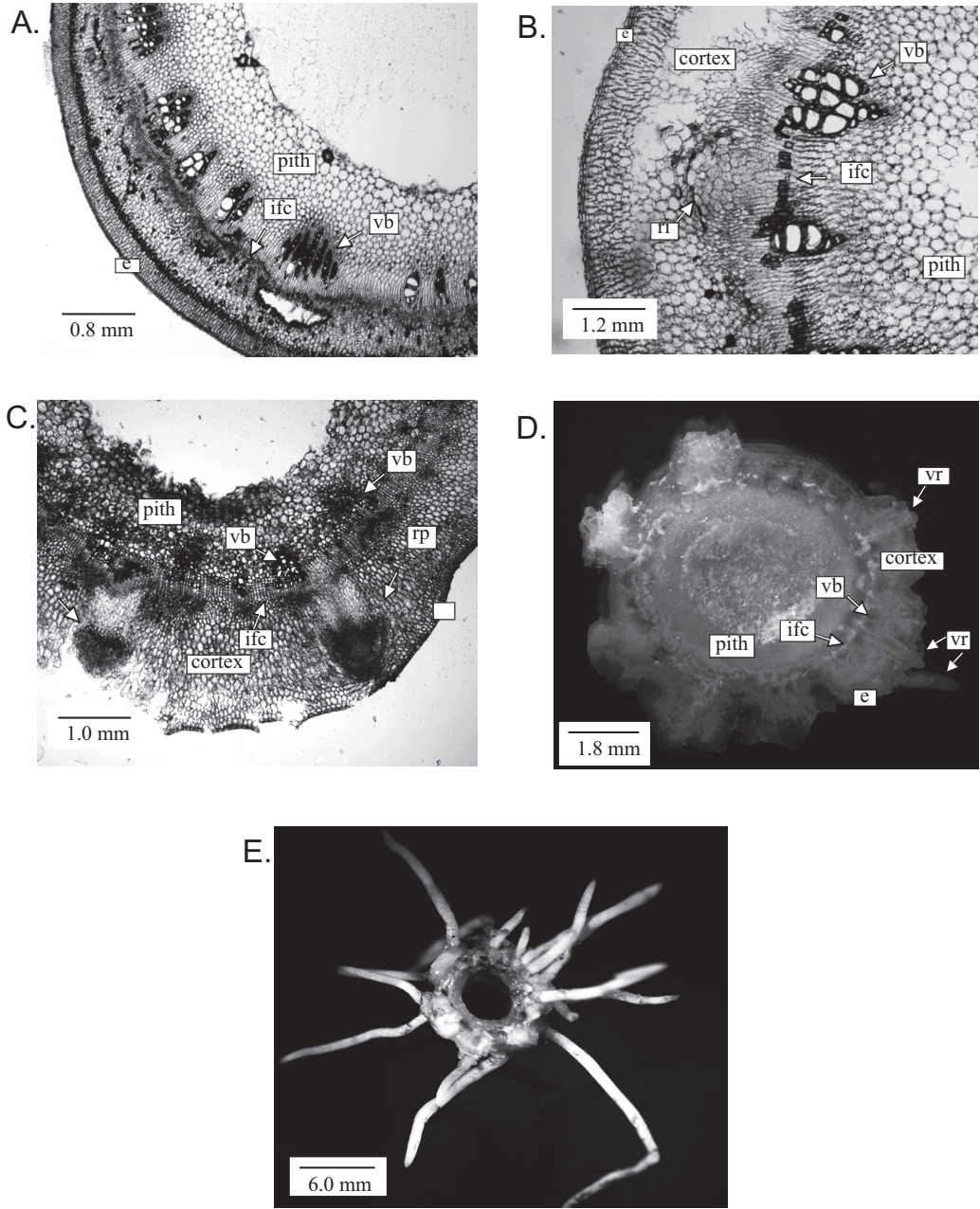

Fig. 1. Stages of root formation in poinsettia cuttings. (A) initial stem anatomy in cross-section (stage 0); (B) undifferentiated cell division prior to organized root initial formation (stage 1); (C) subcuticular root primordia present (stage 2); (D) visible root emergence beyond the epidermis (stage 3); (E) fully rooted with emerged roots $>5 \mathrm{~mm}$ (stage 4). Abbreviations: epidermis (e); interfascicular cambium (ifc); vascular bundle (vb); root initial (ri); root primordia (rp); and visible root (vr).

48 mist events per day. Mist was only provided during the daylight hours. Dynamic control triggered misting events using a set point based on estimated evapotranspiration and used the cutting coefficient calculated from controlled environment studies.

Mineral element Leaching. The elemental content of leaves from cuttings was compared using a constant static (120 mist events per day), a stepped down static (144 to 72 to 48 every $7 \mathrm{~d}$ ) and the dynamic control strategies. Mist was applied only during daylight (12 h) and 144, 120, 72, and 48 mist events per day were derived from static control set to mist every 5, 6, 10, and $15 \mathrm{~min}$, respectively. Nitrogen, phosphorus, and potassium was measured every $7 \mathrm{~d}$, while calcium, magnesium, manganese, copper, and iron was measured at the start and completion ( $21 \mathrm{~d}$ ) of rooting. The most recent fully expanded leaf was sampled from each cutting at each time and three leaves were pooled to make three replicate samples. Each sample was oven-dried at $100{ }^{\circ} \mathrm{C}$ prior to elemental analysis. Nitrogen and phosphorus were measured using a Technicon Autoanalyzer II (Bran and Luebbe, Delavan, Wis.). All other elements were measured by atomic absorption spectrophotometry (Solaar M-5; Thermo Elemental, Franklin, Mass.). The experiment was repeated using cuttings purchased from commercial stock plants with the same results.
STATISTICS. All experiments were completely randomized with the three propagation chambers serving as replications. For rooting stage experiments, the experimental unit was the average of the three randomly selected cuttings per treatment removed from each chamber. Similarly, the experimental units in the relative water content experiments were the average of three randomly selected cuttings for the pre-stress measurement and the remaining nine cuttings for the post-stress measurement. In measuring transpiration rate the experimental unit was either the entire chamber replicated three times, or a tray of 12 cuttings. For statistical analysis, single degree of freedom contrasts or Tukey's least differences tests were used to separate means and linear regression analysis was used to determine cutting coefficient and the relationships between root length and transpiration rate.

\section{Results}

Cell division in the phloem parenchyma was evident between 5 and $10 \mathrm{~d}$ after sticking poinsettia cuttings (Fig. 1; Table 1). Organized subcuticular root primordia were present in 10- to 12-d-old cuttings and visible roots emerged between 12 and $15 \mathrm{~d}$.

Transpiration rate was linear over time for all rooting stages ( $r^{2}$ between 0.89 and 0.99 ) and steady state transpiration was observed in all environments except for non-fully rooted cuttings ( $<21 \mathrm{~d})$ exposed to light and VPDair at $2 \mathrm{kPa}$. In these cases, weight loss in cuttings was determined to be from cutting desiccation rather than transpiration (data not shown). Rooting stage had a significant impact on transpiration rate (Tables 1 and 2). Transpiration increased by nearly $50 \%$ when roots became visible. Light had a significant impact on transpiration capacity only after roots emerged (Table 2). For example, mean transpiration rate for cuttings one week following root emergence showed a 2.5-fold increase between dark and light conditions with VPDair at $2.0 \mathrm{kPa}$. Increasing VPDair from 1.0 to $2.0 \mathrm{kPa}$ had less impact on transpiration rate compared to light (Table 2).

Between visible rooting $(15 \mathrm{~d})$ and $25 \mathrm{~d}$, total root length was linear $\left(r^{2}=0.92\right)$ and highly correlated with transpiration $\left(r^{2}=\right.$ 0.98) (Fig. 2). The ability to significantly sustain transpiration and avoid desiccation under moderate stress (light at $50 \mathrm{~W} / \mathrm{m}^{2}$, and VPDair between 1.5 to $2.0 \mathrm{kPa}$ ) when removed from the mist chamber occurred between 18 and $21 \mathrm{~d}$ (Fig. 2; Tables 1 and 2). This corresponded to the rooting stage when cuttings had a total root system greater than $50 \mathrm{~cm}$ (Fig. 2). At this stage, cuttings transpired at $\approx 0.5 \mathrm{~g}$ of water per hour (Fig. 2), which was sufficient to maintain turgor for the $2 \mathrm{~h}$ of imposed stress as indicated by a nonsignificant difference between pre- and poststress relative water content (Table 1).

Cutting coefficients were calculated as the ratio between transpiration at each rooting stage and transpiration demand (Fig. 3). Cutting coefficients were determined as the slope of each linear regression. Both stages without visible roots had minimal slopes and their cutting coefficient was considered zero. For each successive stage of rooting, regression slopes became progressively closer to transpiration demand. Cutting coefficients were 0.30, 0.46 , and 0.80 for visible rooting, $7 \mathrm{~d}$, and $14 \mathrm{~d}$ after visible rooting, respectively. 
Table 1 . Water relations associated with poinsettia cutting rooting stages.

Relative water content $(\%)$

\begin{tabular}{llll} 
& \multicolumn{2}{c}{ Transpiration } \\
\cline { 3 - 4 } Days & Rooting stage & & \\
$\left(\mathrm{g} \cdot \mathrm{h}^{-1}\right.$ per cutting $)$ & Prestress & Poststress
\end{tabular}

\begin{tabular}{ccccc}
5 & $0 \mathrm{~d}$ & $0.1 \mathrm{c}^{\mathrm{y}}$ & $85 \mathrm{a}$ & $80 \mathrm{~b}$ \\
10 & $0.7 \mathrm{~cd}$ & $0.2 \mathrm{bc}$ & $88 \mathrm{a}$ & $79 \mathrm{~b}$ \\
15 & $3.1 \mathrm{bc}$ & $0.2 \mathrm{bc}$ & $90 \mathrm{a}$ & $82 \mathrm{~b}$ \\
20 & $4.0 \mathrm{a}$ & $0.3 \mathrm{~b}$ & $88 \mathrm{a}$ & $84 \mathrm{a}$ \\
25 & $4.0 \mathrm{a}$ & $0.6 \mathrm{a}$ & $92 \mathrm{a}$ & $90 \mathrm{a}$ \\
\hline
\end{tabular}

zRooting stages were identified as: $0=$ no rooting/cell division; $1=$ cell division evident; $2=$ subcutaneous root primordial; 3 = visible root emergence; $4=$ roots $>1 \mathrm{~mm}$. Values represent the mean of 9 cuttings assigned a stage value at any given day.

y Means within a column followed by the same letter were not different at $\alpha \leq 0.05$ by Tukey's test.

xre- and poststress means were compared at each day using single degree of freedom $\mathrm{F}$ tests.

Table 2. Transpiration rate in poinsettia cuttings at progressive stages of root formation at different levels of vapor pressure deficit in either light or dark conditions.

\begin{tabular}{|c|c|c|c|c|}
\hline \multirow[b]{3}{*}{ Cutting stage } & \multirow[b]{3}{*}{ Light $\left(\mathrm{W} / \mathrm{m}^{2}\right)$} & \multicolumn{3}{|c|}{ Transpiration rate $\left(\mathrm{g} \cdot \mathrm{h}^{-1}\right.$ per cutting) } \\
\hline & & \multicolumn{3}{|c|}{ Air vapor pressure deficit $(\mathrm{kPa})$} \\
\hline & & 1.0 & 1.5 & 2.0 \\
\hline At excision & 0 & $0.066 \mathrm{~b}^{\mathrm{z}}$ & $0.072 \mathrm{~b}$ & $0.096 \mathrm{a}$ \\
\hline$(0 \mathrm{~d})$ & 50 & & $0.071 \mathrm{~b}$ & $0.085 \mathrm{a}$ \\
\hline One week after excision & 0 & $0.104 \mathrm{ab}$ & $0.087 \mathrm{~b}$ & $0.104 \mathrm{ab}$ \\
\hline$(7 \mathrm{~d})$ & 50 & & $0.094 \mathrm{ab}$ & $0.107 \mathrm{a}$ \\
\hline Visible root emergence & 0 & $0.120 \mathrm{~b}$ & $0.122 \mathrm{~b}$ & $0.173 \mathrm{~b}$ \\
\hline$(14 \mathrm{~d})$ & 50 & & $0.162 \mathrm{~b}$ & $0.311 \mathrm{a}$ \\
\hline \multirow{2}{*}{$\begin{array}{l}\text { One week following root } \\
\text { emergence }(21 \mathrm{~d})\end{array}$} & 0 & $0.148 \mathrm{c}$ & $0.158 \mathrm{c}$ & $0.191 \mathrm{c}$ \\
\hline & 50 & & $0.316 \mathrm{~b}$ & $0.469 \mathrm{a}$ \\
\hline \multirow{3}{*}{$\begin{array}{l}\text { Fully rooted cutting } \\
\qquad(28 \mathrm{~d})\end{array}$} & 0 & $0.182 \mathrm{~d}$ & $0.201 \mathrm{c}$ & $0.314 \mathrm{c}$ \\
\hline & 50 & & $0.772 b$ & $0.859 \mathrm{~b}$ \\
\hline & 200 & & & $1.445 \mathrm{a}$ \\
\hline
\end{tabular}

$\begin{array}{ll}\underline{\text { Main and interaction effects }} & \underline{P \text { value }} \\ \text { Cutting stage } & 0.3 \times 10^{-6} \\ \text { Light } & 0.011 \\ \text { Air vapor pressure deficit (VPDair) } & 0.356 \\ \text { Dark vs. light at VPDair } 1.5 \mathrm{kPa} & 0.095 \\ \text { Dark vs. light at VPDair } 2.0 \mathrm{kPa} & 0.067 \\ \text { VPDair } 1.5 \mathrm{vs} .2 .0 \mathrm{kPa} \text { in dark } & 0.133 \\ \text { VPDair } 1.5 \mathrm{vs} .2 .0 \mathrm{kPa} \text { in light } & 0.523\end{array}$

${ }^{2}$ Means within a cutting stage followed by the same letter were not different $\alpha \leq 0.05$ by Tukey's test.
Dynamic control used 56\% less water compared to the static step-down control system (Table 3). However, cutting performance as measured by the number of roots per cutting, overall root length, and proportion of large diameter to small diameter roots was the same between the two misting control systems (Table 4). This experiment was conducted during July, a time typical for commercial poinsettia cutting propagation, but numerous experiments conducted over a two year period from May to September also showed no difference in rooting performance comparing static and dynamic control (data not shown).

Cuttings rooted under constant static mist, step-down static mist, and dynamic control provided three levels of water applied to the cuttings (Table 5), but mineral analysis showed essentially the same pattern of nutrient loss between misting treatments (Table 6). Leaves showed a significant loss of nitrogen, phosphorus, and potassium after only $7 \mathrm{~d}$ in the mist bench, but there was no correlation with the number of mist events during that period. There was a small but significant trend for greater loss of $\mathrm{N}$ and $\mathrm{P}$ using dynamic misting after $14 \mathrm{~d}$. Manganese and iron were also reduced after $21 \mathrm{~d}$ with no correlation to mist interval. Magnesium levels did not change during this study, while calcium and copper concentrations increased after $21 \mathrm{~d}$. Only copper concentration showed a significant and negative correlation with mist interval $\left(r^{2}=0.62\right)$.

\section{Discussion}

This study clearly showed that transpiration capacity only increased after visible roots were formed (Tables 1 and 2). However, cuttings must be well-rooted (total length $>50 \mathrm{~cm}$ ) to obtain enough water from the medium to sustain transpiration under a moderate VPDair stress. It is generally accepted that following initial severance of the cutting from the plant, stomates close and there is a concomitant reduction in transpiration, and gas exchange (Loach, 1988). In poinsettia cuttings, light significantly increased transpiration capacity only following root emergence (Table 2). It was probable that this is due to the combined effects of a reduced ability for cuttings to remove water from the medium without visible roots and that stomates were not responding to light prior to root emergence.

Several studies related gas exchange to cutting water relations as an indication of ability to transpire (Davis, 1988; Loach, 1988). In poinsettia cuttings rooted in high humidity chambers $(85 \%$ to $95 \%$ relative humidity at $24{ }^{\circ} \mathrm{C}$ ), this shift to increased gas exchange occurred after subcuticular root primordia formation, and significantly increased after roots emerged (Svenson et al., 1995). They showed that after root emergence $(15 \mathrm{~d})$, gas exchange and photosynthetic rate tripled. Assuming that cuttings rooted at a similar rate between Svenson 


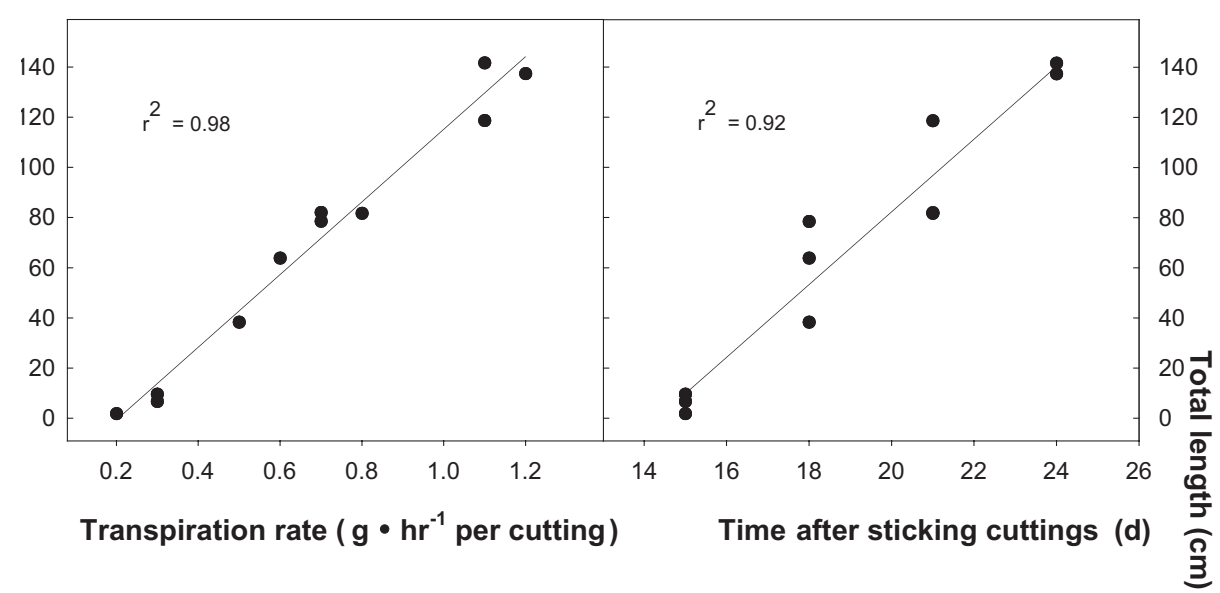

Fig. 2. The relationship between total root length and stage of rooting on transpiration rate in poinsettia cuttings rooted at $25{ }^{\circ} \mathrm{C}$. Transpiration environment was $240 \mathrm{~W} / \mathrm{m}^{2}$ radiant load and $0.8 \mathrm{kPa}$ VPDair. Regression equation for days vs. root length was [root length $=14.50$ (day) -207.71 ]; and for root length vs. transpiration the equation was [transpiration $=0.0067$ (root length $)+0.22]$.

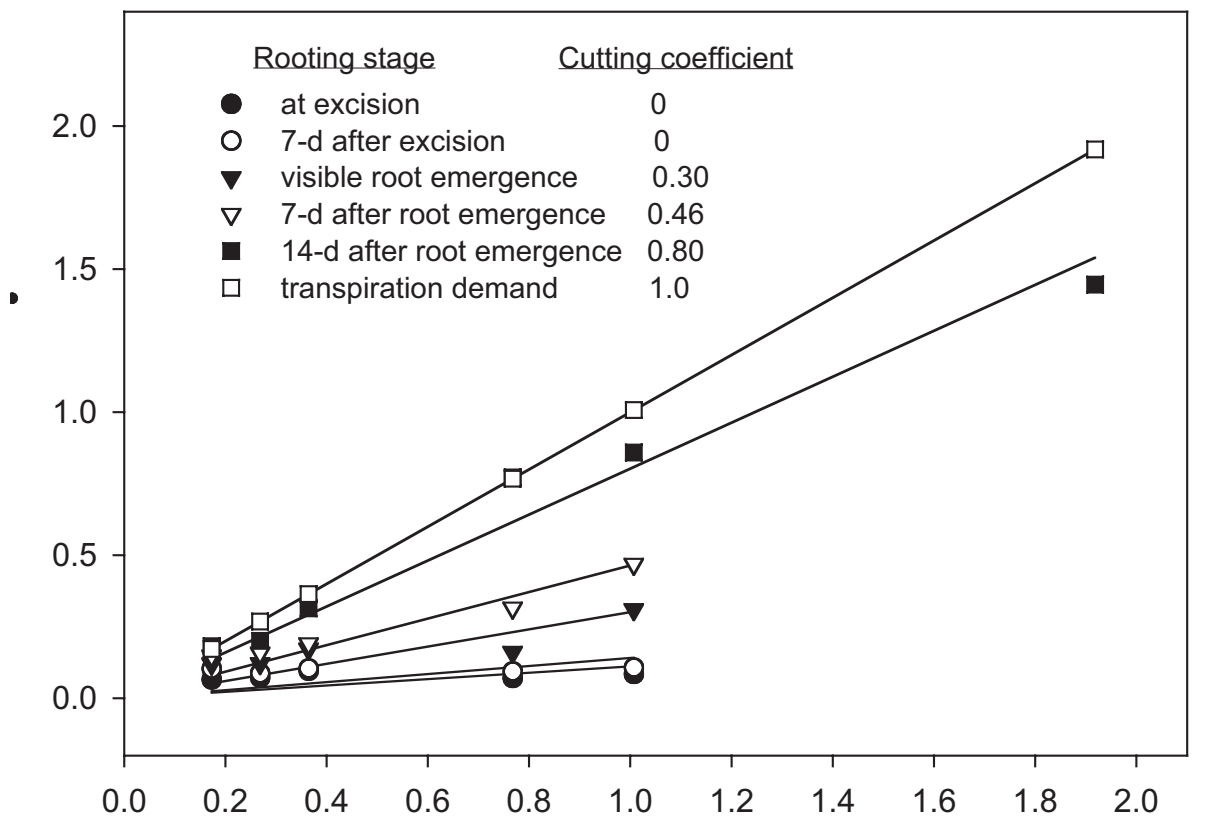

Estimated transpiration for fully rooted cuttings $\left(\mathrm{g} \bullet \mathrm{hr}^{-1}\right.$ per cutting)

Fig. 3. Transpiration in poinsettia cuttings at various light and air vapor pressure levels regressed against transpiration estimated in fully rooted cuttings using the Penman-Monteith equation. The cutting coefficient is the slope of the linear regression.

et al. (1995) and the current study, $15 \mathrm{~d}$ would correspond to the cutting stage where gas exchange and stomatal conductance increased significantly (Svenson et al., 1995). However, it was not until $18 \mathrm{~d}$ that transpiration became sufficient to maintain the cuttings water status as indicated by pre- and poststress relative water content (Table 1). Comparison of the two studies suggests that under non-stressful conditions, poinsettia cuttings stomates become responsive at root emergence, but under moderate stress substantially more roots must be present to maintain water balance from transpirational loss. Previous studies have shown that cuttings in some species show increased ability for gas exchange or photosynthetic capacity prior to visible rooting (Svenson et al., 1995; von Schaesberg et al., 1993), while others must have substantial root emergence (Feldmann et al., 1989; Gay and Loach,
1977). The differences may be due to the stress (VPDair) under which the studies were conducted.

It is not clear whether the increased capacity for photosynthetic gas exchange in cuttings is driven by improved water relations or some other signal (i.e., hormonal-Hubick et al., 1988; Smalley et al., 1991; source/sink-Feldmann et al., 1989; Loach and Gay, 1979).

The present study suggests that improved water relations would seem insufficient to start the initial increase in gas exchange seen in poinsettia cuttings, but would support the dramatic, sustained increase observed once cuttings were fully rooted.

Astep-wise decrease in mist frequency was added to the dynamic evapotranspiration control system by using the cutting coefficient to match transpiration demand. Greenhouse studies generally validated the use of the cutting coefficient with the evapotranspiration system compared to static control systems (Tables 3 and 4). It was shown that a traditional step-down static system applied more water than was necessary to achieve adequate rooting. The dynamic system reduced overall water usage, but at times applied mist more frequently than static systems when the VPDair levels were severe $(>1.5 \mathrm{kPa}$; data not shown).

Loss of foliar nutrients is a common observation during cutting propagation and can be visually evident in poinsettia cuttings. It was hypothesized that reduced mist frequency would reduce foliar leaching of nutrients (Blazich, 1988). However, there was no correlation between the change in foliar elemental content and mist frequency. Svenson and Davies (1995) measured mineral element content during propagation of poinsettia cuttings under high humidity rather than mist. In general, they observed less nutrient loss in leaves compared to the current study, but still reported significant major nutrient element loss after $14 \mathrm{~d}$. This suggests that water applied to poinsettia leaves contributes to nutrient leaching, but is not the only factor involved. Also, some mobile elements may have been reallocated to the base of the cutting to support new root formation further reducing foliar nutrients.

\section{Conclusion}

To our knowledge, this is the first description of transpiration capacity in cuttings measured at discrete rooting stages using population and single cutting data. Combining the power of the Penmen-Monteith equation to calculate transpiration with our measured transpiration capacity data, a cutting coefficient was derived to account for water uptake as a function of root system 
Table 3. Mist frequency and environmental conditions comparing static, and dynamic (evapotranspiration model) misting control in poinsettia cuttings during July.

\begin{tabular}{|c|c|c|c|c|c|}
\hline \multirow{2}{*}{$\begin{array}{l}\text { Time after } \\
\text { sticking (d) }\end{array}$} & \multicolumn{2}{|c|}{ No. of misting events } & \multirow{2}{*}{$\begin{array}{l}\text { Total light } \\
\left(\mathrm{mol} \cdot \mathrm{m}^{-2}\right)^{\mathrm{z}}\end{array}$} & \multirow{2}{*}{$\begin{array}{c}\text { Mean daytime } \\
\text { temp }\left({ }^{\circ} \mathrm{C}\right)\end{array}$} & \multirow{2}{*}{$\begin{array}{l}\text { Avg daytime } \\
\text { VPDair }(\mathrm{kPa})\end{array}$} \\
\hline & Static & Dynamic & & & \\
\hline 1 & 144 & 63 & 56.3 & 25.1 & 0.99 \\
\hline 2 & 144 & 52 & 48.7 & 27.1 & 0.75 \\
\hline 3 & 144 & 43 & 42 & 27.6 & 0.60 \\
\hline 4 & 144 & 28 & 30.4 & 26.5 & 0.46 \\
\hline 5 & 144 & 27 & 27.3 & 25.8 & 0.32 \\
\hline 6 & 144 & 35 & 35.1 & 26.3 & 0.60 \\
\hline 7 & 144 & 45 & 47.6 & 26.4 & 0.63 \\
\hline 8 & 72 & 49 & 51 & 25.4 & 0.80 \\
\hline 9 & 72 & 49 & 51 & 25.8 & 0.81 \\
\hline 10 & 72 & 53 & 55.5 & 26.4 & 0.95 \\
\hline 11 & 72 & 27 & 27.4 & 25.6 & 0.54 \\
\hline 12 & 72 & 35 & 6.1 & 22.0 & 0.26 \\
\hline 13 & 72 & 40 & 33.8 & 25.4 & 0.90 \\
\hline 14 & 48 & 38 & 36 & 25.3 & 0.83 \\
\hline 15 & 48 & 49 & 43.2 & 25.4 & 1.21 \\
\hline 16 & 48 & 47 & 39.2 & 25.2 & 1.14 \\
\hline 17 & 48 & 40 & 51.6 & 25.2 & 1.18 \\
\hline 18 & 48 & 29 & 41.8 & 25.6 & 0.83 \\
\hline 19 & 48 & 25 & 38.8 & 25.8 & 0.68 \\
\hline 20 & 48 & 19 & 28.4 & 24.8 & 0.50 \\
\hline
\end{tabular}

$\overline{{ }^{2} \text { Light was measured outside greenhouse. Light at cutting height was reduced }}$ by $60 \%$.

Table 4. Root formation in poinsettia cuttings with mist intervals controlled by a static timer or dynamic calculation of evapotranspiration during July.

\begin{tabular}{|c|c|c|}
\hline & Static control & Dynamic control \\
\hline Roots per cutting & $45.5 \mathrm{a}^{\mathrm{z}}$ & $45.3 \mathrm{a}$ \\
\hline \multicolumn{3}{|l|}{ Root length $(\mathrm{cm})$ per cutting } \\
\hline Total length & $259.4 \mathrm{a}$ & $262.1 \mathrm{a}$ \\
\hline $\begin{array}{c}\text { Root length }(\mathrm{cm}) \text { per diameter class } \\
<0.8 \mathrm{~mm}\end{array}$ & $124.1 \mathrm{a}$ & $127.5 \mathrm{a}$ \\
\hline$>0.8 \mathrm{~mm}$ & $135.5 \mathrm{a}$ & $134.4 \mathrm{a}$ \\
\hline Root dry weight (mg) per cutting & $89.2 \mathrm{a}$ & $96.4 \mathrm{a}$ \\
\hline
\end{tabular}

${ }^{2}$ Means in a row followed by the same letter were not significantly different at $P$ $\leq 0.05$ as determined by single degree of freedom $\mathrm{F}$ test.

development. The utility of this cutting coefficient was validated under greenhouse conditions with a significant reduction in water usage. The evapotranspiration-based control system (Zolnier et al., 2003) has been used successfully over three years for rooting poinsettia cuttings under full sun and shaded conditions (data not shown). In over 12 greenhouse experiments, rooting was equivalent in cuttings misted by static and evapotranspirationbased control. Less water usage was the major benefit to using the evapotranspiration-based control system. Other potential benefits for significantly improved rooting or reduced foliar nutrient loss were not realized. Future research will develop a model to predict time to visible root formation and subsequent root elongation based on the propagation environment to further define the relationship between transpiration, cutting coefficient, and the frequency of misting events.
Table 5. Mist frequency and environmental conditions comparing static, stepped and dynamic (evapotranspiration model) misting control in poinsettia cuttings during July.

\begin{tabular}{|c|c|c|c|c|c|c|}
\hline \multirow[b]{2}{*}{$\begin{array}{l}\text { Time after } \\
\text { sticking (d) }\end{array}$} & \multicolumn{3}{|c|}{ No. of misting events } & \multirow[b]{2}{*}{$\begin{array}{l}\text { Total light } \\
\left(\mathrm{mol} \cdot \mathrm{m}^{-2}\right)\end{array}$} & \multirow[b]{2}{*}{$\begin{array}{c}\text { Mean daytime } \\
\text { temp }\left({ }^{\circ} \mathrm{C}\right)\end{array}$} & \multirow{2}{*}{$\begin{array}{c}\text { Avg daytime } \\
\text { VPDair } \\
(\mathrm{kPa})\end{array}$} \\
\hline & Static & Stepped & Dynamic & & & \\
\hline 1 & 120 & 144 & 39 & 30.6 & 26.6 & 0.58 \\
\hline 2 & 120 & 144 & 39 & 33.0 & 26.9 & 0.64 \\
\hline 3 & 120 & 144 & 44 & 38.2 & 26.9 & 0.65 \\
\hline 4 & 120 & 144 & 37 & 29.7 & 26.8 & 0.65 \\
\hline 5 & 120 & 144 & 46 & 37.5 & 27.9 & 0.71 \\
\hline 6 & 120 & 144 & 51 & 40.8 & 28.7 & 0.84 \\
\hline 7 & 120 & 72 & 44 & 35.1 & 28.0 & 0.75 \\
\hline 8 & 120 & 71 & 22 & 10.1 & 24.3 & 0.37 \\
\hline 9 & 120 & 72 & 54 & 46.9 & 26.1 & 0.65 \\
\hline 10 & 120 & 72 & 31 & 22.9 & 25.7 & 0.51 \\
\hline 11 & 120 & 71 & 39 & 30.8 & 26.5 & 0.53 \\
\hline 12 & 120 & 72 & 48 & 39.8 & 27.3 & 0.70 \\
\hline 13 & 120 & 72 & 47 & 34.1 & 27.3 & 0.80 \\
\hline 14 & 120 & 48 & 43 & 35.9 & 28.1 & 0.90 \\
\hline 15 & 120 & 48 & 40 & 34.5 & 28.2 & 0.86 \\
\hline 16 & 120 & 45 & 27 & 22.5 & 26.1 & 0.58 \\
\hline 17 & 120 & 48 & 34 & 28.9 & 26.0 & 0.40 \\
\hline 18 & 120 & 48 & 44 & 39.0 & 27.4 & 0.92 \\
\hline 19 & 120 & 48 & 32 & 27.2 & 27.4 & 0.72 \\
\hline Totals & 2280 & 1651 & 761 & 617.5 & --- & --- \\
\hline Means & --- & --- & -- & 32.5 & 25.6 & 0.67 \\
\hline
\end{tabular}

$\overline{\text { zLight was measured outside greenhouse. Light at cutting height was reduced }}$ by $60 \%$.

\section{Literature Cited}

Blazich, F.A. 1988. Mineral nutrition and adventitious rooting, p. 79-87. In: T.D. Davis, B.E. Haissig, and N. Sankhla (eds.). Adventitious root formation in cuttings. Dioscorides Press, Portland, Ore.

Davis, T.D. 1988. Photosynthesis during adventitious rooting, p. 79-87. In: T.D. Davis, B.E. Haissig, and N. Sankhla (eds.). Adventitious root formation in cuttings. Dioscorides Press, Portland, Ore.

Feldman, W.R., D.A. Palzkill, A.K. Dobrenze, and L. Hogan. 1989. Carbon dioxide exchange during mist propagation of jojoba cuttings. Agron. J. 81:233-236.

Gay, A.P. and K. Loach. 1977. Leaf conductance changes on leafy cuttings of Cornus and Rhododendron during propagation. J. Hort. Sci. 52:509-516.

Geneve, R.L., S.T. Kester, and J.W. Buxton. 2004. Capillary mats alter the water content in medium during mist propagation of Dendranthema. HortScience 39:584-587.

Geneve, R.L. and S.T. Kester. 2001. Evaluation of seedling size following germination using computer-aided analysis of digital images from a flat bed scanner. HortScience 36:117-20.

Gislerød, H.R. 1983. Physical conditions of propagation media and their influence on the rooting of cuttings: III. The effect of air content and temperature in different propagation media on the rooting of cuttings. Plant and Soil 75:1-14.

Hubick, K.T., J.S. Taylor, and D.M. Reid. 1988. The effect of drought on levels of abscisic acid, cytokinins, gibberellins and ethylene in aeroponically-grown sunflower plants. Plant Growth Regulat. 4:139-400.

Hartmann, H.T., D.E. Kester, F.T. Davies, Jr., and R.L. Geneve. 2002. Hartmann and Kester's Plant propagation-Principles and practice. 7th ed. Prentice Hall, Upper Saddle River, N.J.

Loach, K. 1988. Water relations and adventitious rooting, p. 104-116. In: T.D. Davis, B.E. Haissig, and N. Sankhla (eds.). Adventitious root formation in cuttings. Dioscorides Press, Portland, Ore. 
Table 6. Change in nutritional status of poinsettia cutting leaves using static, stepped and dynamic (evapotranspiration model) misting control in poinsettia cuttings during July.

\begin{tabular}{|c|c|c|c|c|c|c|c|c|c|}
\hline \multirow[b]{2}{*}{ Time (d) } & \multicolumn{9}{|c|}{ Mist control system } \\
\hline & Static & Step & Dynamic & Static & Step & Dynamic & Static & Step & Dynamic \\
\hline & \multicolumn{3}{|c|}{ Nitrogen $(\%)$} & \multicolumn{3}{|c|}{ Phosphorus (\%) } & \multicolumn{3}{|c|}{ Potassium (\%) } \\
\hline 0 & $5.1 \mathrm{a}^{\mathrm{z}}$ & $5.1 \mathrm{a}$ & $5.1 \mathrm{a}$ & $0.84 \mathrm{a}$ & $0.84 \mathrm{a}$ & $0.84 \mathrm{a}$ & $2.5 \mathrm{a}$ & $2.5 \mathrm{a}$ & $2.5 \mathrm{a}$ \\
\hline 7 & $3.5 \mathrm{bA}$ & $3.9 \mathrm{bA}$ & $3.4 \mathrm{bA}$ & $0.62 \mathrm{bA}$ & $0.71 \mathrm{bA}$ & $0.62 \mathrm{bA}$ & $1.6 \mathrm{bA}$ & $1.6 \mathrm{bA}$ & $1.6 \mathrm{bA}$ \\
\hline 14 & $2.9 \mathrm{cA}$ & $2.8 \mathrm{cA}$ & $2.5 \mathrm{cB}$ & $0.56 \mathrm{bA}$ & $0.54 \mathrm{cB}$ & $0.52 \mathrm{cC}$ & $1.3 \mathrm{cA}$ & $1.0 \mathrm{cB}$ & $1.3 \mathrm{bA}$ \\
\hline \multirow[t]{2}{*}{21} & $2.6 \mathrm{cA}$ & $2.3 \mathrm{~dB}$ & $2.1 \mathrm{dC}$ & $0.54 \mathrm{bA}$ & $0.49 \mathrm{cB}$ & $0.42 \mathrm{dC}$ & $1.3 \mathrm{cB}$ & $1.6 \mathrm{bA}$ & $1.0 \mathrm{cC}$ \\
\hline & \multicolumn{3}{|c|}{ Calcium (\%) } & \multicolumn{3}{|c|}{ Magnesium (\%) } & \multicolumn{3}{|c|}{ Manganese $\left(\mu \mathrm{g} \cdot \mathrm{g}^{-1}\right)$} \\
\hline 0 & $0.28 \mathrm{~b}$ & $0.28 \mathrm{~b}$ & $0.28 \mathrm{~b}$ & $0.23 \mathrm{a}$ & $0.23 \mathrm{a}$ & $0.23 \mathrm{a}$ & $35.7 \mathrm{a}$ & $35.7 \mathrm{a}$ & $35.7 \mathrm{a}$ \\
\hline \multirow[t]{2}{*}{21} & $0.49 \mathrm{aA}$ & $0.52 \mathrm{aA}$ & $0.51 \mathrm{aA}$ & $0.20 \mathrm{aA}$ & $0.24 \mathrm{aA}$ & $0.22 \mathrm{aA}$ & $14.1 \mathrm{bB}$ & $21.1 \mathrm{bA}$ & $14.7 \mathrm{bB}$ \\
\hline & \multicolumn{3}{|c|}{ Copper $\left(\mu \mathrm{g} \cdot \mathrm{g}^{-1}\right)$} & \multicolumn{3}{|c|}{ Iron $\left(\mu \mathrm{g} \cdot \mathrm{g}^{-1}\right)$} & & & \\
\hline 0 & $5.8 \mathrm{~b}$ & $5.8 \mathrm{~b}$ & $5.8 \mathrm{~b}$ & $46.8 \mathrm{a}$ & $46.8 \mathrm{a}$ & $46.8 \mathrm{a}$ & & & \\
\hline 21 & $34.2 \mathrm{aA}$ & $20.7 \mathrm{aB}$ & $21.0 \mathrm{aB}$ & $38.2 \mathrm{bA}$ & $40.1 \mathrm{aA}$ & $33.7 \mathrm{bA}$ & & & \\
\hline
\end{tabular}

${ }^{2}$ Means within a column followed by the same lowercase letter or within a row followed by the same uppercase letter for each element were not different by Tukey's $(\alpha \leq 0.05)$.

Loach, K. and A.P. Gay. 1979. The light requirement for propagating hardy ornamental species from leafy cuttings. Scientia Hort. 10:217-230.

Smalley, T.J., M.A. Dirr, A.M. Armitage, B.W. Wood, R.O. Teskey, and R.F. Severson. 1991. Photosynthesis and leaf water, carbohydrate, and hormone status during rooting of stem cuttings of Acer rubrum. J. Amer. Soc. Hort. Sci. 116:1052-1057.

Svenson, S.E. and F.T. Davies, Jr. 1995. Change in tissue mineral elemental concentration during root initiation and development of poinsettia cuttings. HortScience 30:617-619.

Svenson, S.E., F.T. Davies, Jr., and S.A. Duray. 1995. Gas exchange, water relations, and dry weight partitioning during root initiation and development of poinsettia cuttings. J. Amer. Soc. Hort. Sci. 120:454-459.

Turner, N.C. 1981. Techniques and experimental approaches for the measurement of plant water status. Plant and Soil 58:339-366. von Schaesberg, N., G. Ebert, and P. Ludders. 1993. Leaf gas exchange of mango (Mangifera indica L.) cuttings during adventitious root formation. Angew. Bot. 67:14-16.

Wilkerson, E.G. and R.S. Gates. 2003. Controlled environment system for studying root zone temperature effects on cutting propagation. Appl. Eng. Agr. 19:483-489.

Zolnier, S. 1999. Dynamic misting control techniques for poinsettia propagation. PhD Diss., Biosystems and Agr. Eng. Dept., Univ. of Kentucky, Lexington.

Zolnier, S., R.S. Gates, R.L. Geneve, and J.W. Buxton. 2001. Surface diffusive resistances of rooted poinsettia cuttings under controlledenvironment conditions. Trans. Amer. Soc. Agr. Eng. 44:1779-1787.

Zolnier, S., R.S. Gates, R.L. Geneve, and J.W. Buxton. 2003. Evapotranspiration model-based mist control for poinsettia propagation. Trans. Amer. Soc. Agr. Eng. 46:135-145. 